15 Hrubec $Z$, Cederlof R, Friberg $L$. Background of angina pectoris: social and environmental factors in relation to smoking. Am $\mathcal{J}$ Epidemiol 1976;103:16-29.

16 Morris JN, Kagan A, Patterson DC, et al. Incidence and prediction of ischaemic heart disease in London busmen. Lancet 1966;ii:553-9.

17 Doyle JT, Heslem AS, Hilleboe HE, et al. A prospective study of degenerative cardiovascular disease in Albany: report of three years' experience. Ischemic heart disease. Am 7 Public Health disease in Albany: repo:t

18 Kittner SJ, Garcia-Palmieri MR, Costas R, Cruz-Vidal M, Abbott RD, Havlik RJ. Alcohol and coronary heart disease in Puerto Rico. Am F Epidemiol 1983;117:538-50.

19 Marmot MG, Rose G, Shipley MJ, Thomas BJ. Alcohol and mortality: a U-shaped curve. Lance 1981;i:580-3.

20 Hennekens $\mathrm{CH}$, Rosner B, Cole DS. Daily alcohol consumption and fatal coronary heart disease. Am $\mathcal{F}$ Epidemiol 1978;107:196-200.

21 Cabot RC. The relation of alcohol to arteriosclerosis. JAMA 1904;43:774-5.

22 Barboriak JJ, Rimm AA, Anderson AJ, et al. Coronary artery occlusion and alcohol intake. Br Hear f 1977;39:289-93.

23 Jones BR, Barret-Connor E, Criqui MH, Holdbrook MJ. A community study of calorie and nutrient intake in drinkers and non-drinkers of alcohol. Am 7 Clin Nutr 1982;35:135-9.

24 Dyer AR, Stamler J, Lepper MH, Shekelle RB, McKean H, Garside D. Alcohol consumption and 17-year morbidity in the Chicago Western Electric Co study. Prev Med 1980;9:78-90.

25 Dyer AR, Stamler J, Paul O, et al. Alcohol, cardiovascular risk factors and mortality; the Chicago experience. Circulation 1981;64 (suppl 111):20-7.

26 Gordon T, Kagan A, Garcia-Palmieri M, et al. Diet and its relation to coronary heart disease and death in three populations. Circulation 1981;63:500-15.

27 Gordon T, Kannel WB. Drinking habits and cardiovascular disease: the Framingham study. Am Heart f 1983;105:667-77.
28 Yano K, Rhoads GG, Kagan A. Coffee, alcohol and risk of coronary heart disease among Japanese men living in Hawaii. N Engl I Med 1977;279:405-9.

29 Blackwelder WC, Yano K, Rhoads GG, Kagan A, Gordon T, Palesch Y. Alcohol and mortality: the Honolulu heart study. Am f Med 1980;68:164-9.

30 Kagan A, Yano K, Rhoads GG, McGee DL. Alcohol and cardiovascular disease: the Hawaiian experience. Circularion 1981;64 (suppl 111):27-31.

31 Garcia-Palmieri MR, Sorlie P, Tillotson J, Costas R, Cosdero E, Rodriguez M. Relationship of dietary intake to subsequent coronary heart disease incidence: the Puerto Rico heart health program. Am $\mathcal{J}$ Clin Nutr 1980;33:1818-27.

32 Cullen K, Stenhouse NS, Wearne KL. Alcohol and mortality in the Busselton study Int $\mathcal{J}$ Epidemiol 1982;11:67-70.

33 Marmot MG, Rose G, Shipley MJ. Alcohol and mortality. Lancet $1981 ; 1: 1159$

34 Kozarevic DJ, McGee D, Vojrvodic N, et al. Frequency of alcohol consumption and morbidity and mortality: the Yugoslavia cardiovascular disease study. Lancet 1980;i:613-6.

35 Kozarevic D, Demirovic J, Gordon T, Kaelber CT, McGee D, Zukel WJ. Drinking habits and coronary heart disease: the Yugoslavia cardiovascular disease study. Am f E pidemiol 1982;116: 748-58.

36 Klatsky AL, Friedman GO, Siegelaub AB. Alcohol and mortality. A ten-year Kaiser-Permanente experience. Ann Intern Med 1981;95:139-45.

37 Klatsky AL, Friedman GO, Siegelaub AB. Alcohol consumption before myocardial infarction: results from the Kaiser-Permanente study of myocardial infarction. Ann Intern Med 1974;81: 294-301.

38 Klatsky AL, Friedman GD, Siegalaub MS. Alcohol use and cardiovascular disease: the Kaiser Permanente experience. Circulation 1981;64 (suppl 111):32-41.

(Accepted 5 February 1987)

\title{
Congenital rubella in babies of south Asian women in England and Wales: an excess and its causes
}

\author{
ELIZABETH MILLER, ANGUS NICOLL, STEPHEN A ROUSSEAU, PETER J L SEQUEIRA, \\ MILTON H HAMBLING, RICHARD W SMITHELLS, HELEN HOLZEL
}

\begin{abstract}
The incidence of congenital rubella was found to be 2.3 times higher in Asian than non-Asian births in England and Wales. This was attributed in part to higher susceptibility to rubella in Asian than non-Asian women, as shown by antenatal serological data from public health laboratories in Leeds, Luton, and Manchester. Examination of the ethnic origin of pregnant women requesting laboratory testing after contact with rubella or rash and of women with laboratory confirmed rubella in pregnancy also suggested that the disease was being underdiagnosed in pregnant Asian women. Failure to prevent congenital rubella by termination of infected pregnancies may therefore contribute to the increased incidence of the syndrome in Asians.
\end{abstract}

PHLS Communicable Dísease Surveillance Centre, London NW9 5HT ELIZABETH MILLER, MB, BSC, principal microbiologist

University of Nottingham, Department of Child Health, Queen's Medical Centre, Nottingham NG7 2UH

ANGUS NICOLL, MRCP, lecturer in child health

Public Health Laboratory, Luton and Dunstable Hospital, Luton LU4 0DZ STEPHEN A ROUSSEAU, MRCPATH, DOBSTRCOG, consultant microbiologist

Central Serology Laboratory, Withington Hospital, Manchester M20 8LR PETER J L SEQUEIRA, MB, BS, laboratory director

Public Health Laboratory, Leeds LS15 7TR

MILTON H HAMBLING, MD, FRCPATH, consultant microbiologist

Department of Paediatrics and Child Health, Clarendon Wing, General Infirmary, Leeds LS2 9NS

RICHARD W SMITHELLS, FRCP, DCH, professor of paediatrics

Hospital for Sick Children, Department for Microbiology, Great Ormond Street, London WC1 3JH

HELEN HOLZEL, MD, MRCPATH, consultant microbiologist

Correspondence and requests for reprints to: Dr Miller.
Health education programmes about the dangers of rubella in pregnancy and of the need for vaccination can readily be promoted in the Asian community through existing ethnic organisations. Protection of other ethnic minorities likely to be at similar increased risk may require a vaccination programme aimed at national elimination of rubella.

\section{Introduction}

Congenital rubella is a cause of severe and permanent disability. An affected child is distressing and burdensome for the family and usually requires lifelong support of health and educatiunal services. Unlike other types of severe handicap, the cause of this condition is both known and preventable, either by vaccination or by terminating infected pregnancies.

The British rubella vaccination policy is to immunise selectively girls while at school and non-immune adult women before or after pregnancy. It is therefore important to seek out and concentrate resources on those women most likely to be at risk. A study at a London antenatal clinic showed one such group to be ethnic south Asians (immigrants from India, Pakistan, Bangladesh, or Sri Lanka or east African Asians; for simplicity referred to here as Asians), since susceptibility to rubella was higher in these patients than in non-Asian women. ${ }^{1}$ We have investigated this finding by comparing susceptibility in Asian and non-Asian antenatal patients elsewhere in Britain. We have also compared the incidence of confirmed rubella infection in pregnancy as well as that of notified congenital rubella in Asian and non-Asian births in England and Wales.

\section{Subjects and methods}

Data on susceptibility to rubella according to age, parity, and ethnic group were obtained for antenatal patients screened by Public Health Laboratory Service laboratories in Manchester, Leeds, and Luton. Since 1984 each laboratory has obtained information on parity for antenatal patients as part of a Public Health Laboratory Service serological surveillance programme. ${ }^{2}$ 
For six months during 1985 the ethnic origin of antenatal patients screened by Manchester and Leeds was recorded in the laboratory using an Asian name bank. ${ }^{3}$ In Luton ethnic origin is routinely requested for antenatal patients. For the period July to December 1984 the ethnic origin of pregnant women requesting diagnostic testing because of contact with or suspected rubella was also recorded by Luton laboratory using the name bank technique. A sample of male blood donors aged 15-40 and men attending occupational health or sexually transmitted disease clinics were also screened for rubella antibodies by the three laboratories during 1984-5.

The names of women with serologically confirmed rubella in pregnancy reported to the Communicable Disease Surveillance Centre by laboratories in England and Wales during 1982-5 were examined for ethnic origin using the name bank technique. The registers of the National Congenital Rubella Surveillance Programme, which receives reports of children with confirmed or suspected congenital rubella, ${ }^{4}$ were examined using the same method for the period 1974-83.

\section{Results}

A total of 2636 Asian antenatal patients were identified, of whom 161 $(6 \cdot 1 \%)$ were susceptible to rubella. By contrast, only $748(2 \cdot 2 \%)$ of the 34768 non-Asian patients tested were non-immune. The difference between Asian and non-Asian women was apparent in antenatal populations from each of the three laboratories and was most pronounced in nulliparous women (table I); the difference between ethnic groups was significant in each parity group $(p<0.05)$. Susceptibility in nulliparous Asian women declined with age $\left(\chi^{2}\right.$ test for trend significant at $5 \%$ level) and was not significantly different from that in men of the same age (table II). In both ethnic groups susceptibility was lower in parous women $(p \ll 0 \cdot 001)$. Overall $69 \%$ of the Asian women identified had had one or more previous births compared with $53 \%$ of the non-Asians.

In the Luton antenatal population during 1984 a significantly lower proportion of Asian patients requested diagnostic testing because of contact with or suspected rubella in pregnancy than non-Asian women $(p<0.005)$ (table III).

The names of 733 women resident in Britain and reported to the Communicable Disease Surveillance Centre with confirmed rubella in

TABLE I-Proportion of Asian and non-Asian antenatal patients of various parities susceptible to rubella (Manchester, Leeds, and Luton 1984-5)

\begin{tabular}{lccccc}
\hline & \multicolumn{2}{c}{ Asians } & & \multicolumn{2}{c}{ Non-Asians } \\
\cline { 2 - 3 } \cline { 5 - 6 } Parity & No tested & No (\%) negative & & No tested & No (\%) negative \\
\hline 0 & 812 & $86(10 \cdot 6)$ & & 16237 & $420(2 \cdot 6)$ \\
1 & 472 & $16(3 \cdot 4)$ & & 5877 & $88(1 \cdot 5)$ \\
& 1017 & $28(2 \cdot 8)$ & & 4208 & $75(1 \cdot 8)$ \\
\hline
\end{tabular}

TABLE II-Proportions of men and of nulliparous Asian and non-Asian antenatal patients of various age groups susceptible to rubella (Manchester, Leeds, and Luton 1984-5)

\begin{tabular}{|c|c|c|c|c|c|c|}
\hline & \multicolumn{6}{|c|}{ Age groups (years) } \\
\hline & \multicolumn{2}{|c|}{$15-19$} & \multicolumn{2}{|c|}{$20-29$} & \multicolumn{2}{|c|}{$\geqslant 30$} \\
\hline & No tested & $\begin{array}{c}\text { No }(\%) \\
\text { negative }\end{array}$ & No tested & $\begin{array}{c}\text { No }(\%) \\
\text { negative }\end{array}$ & No tested & $\begin{array}{c}\text { No(\%) } \\
\text { negative }\end{array}$ \\
\hline $\begin{array}{l}\text { Non-Asians para } 0 \\
\text { Asians para } 0 \\
\text { Males }\end{array}$ & $\begin{array}{r}3939 \\
182 \\
483\end{array}$ & $\begin{array}{l}99(2 \cdot 5) \\
24(13 \cdot 2) \\
68(14 \cdot 1)\end{array}$ & $\begin{array}{r}9934 \\
477 \\
1197\end{array}$ & $\begin{array}{r}266(2 \cdot 7) \\
44(9 \cdot 2) \\
101(8 \cdot 4)\end{array}$ & $\begin{array}{r}1725 \\
58 \\
728\end{array}$ & $\begin{array}{r}57(3 \cdot 3) \\
3(5 \cdot 2) \\
33(4 \cdot 5)\end{array}$ \\
\hline
\end{tabular}

TABLE III-Number of requests for routine antenatal rubella screening and number of pregnant patients requesting diagnostic investigation for rubella according to ethnic group (Luton 1984)

\begin{tabular}{lccc}
\hline & & $\begin{array}{c}\text { Pregnant women tested for contact with } \\
\text { or suspected rubella }\end{array}$ \\
\cline { 3 - 4 } Ethnic group & $\begin{array}{c}\text { Requests for routine } \\
\text { antenatal rubella screening }\end{array}$ & No & $\begin{array}{c}\text { \% Of } \\
\text { antenatal population }\end{array}$ \\
\hline Asian & 348 & 6 & $1 \cdot 7$ \\
Non-Asian & 4296 & 245 & $5 \cdot 7$ \\
\hline
\end{tabular}

pregnancy during $1982-5$ were examined. Of these, only $32(4 \cdot 4 \%)$ were of Asian origin compared with $5 \cdot 8 \%$ of the total live births in England and Wales during the same period. 56

During 1974-83, 312 cases of confirmed and suspected congenital rubella were notified to the national surveillance programme, of which $35(11 \cdot 2 \%)$ were in infants with Asian names. The proportion of total births to Asian mothers over the period was $5 \cdot 4 \%,{ }^{56}$ a significantly lower proportion by Poisson distribution $(p<0.001)$. Hence the incidence of notified congenital rubella was $2 \cdot 3$ times greater in Asian than non-Asian women.

\section{Discussion}

This study has confirmed the findings of Peckham et al that Asian women have a higher level of susceptibility to rubella than nonAsians. The main reason seems to be that Asian women miss school immunisation by arriving in Britain after the ages at which this takes place. Pre-pregnancy vaccination of susceptible adult women may be effective in reducing susceptibility in those who miss vaccination at school. ${ }^{2}$ No evidence of this was found in the Asian women in our study, however, as the decline in susceptibility with age in nulliparous Asians was similar to that in men and must therefore result from natural infection during the childbearing years. By contrast, the postpartum vaccination programme has been highly effective, reducing susceptibility in parous Asians to under $3 \%$ and in parous non-Asians to under $2 \%$. In the latter group no decline was found with successive pregnancies, confirming that susceptibility in these women had reached a minimum. ${ }^{27}$

Despite their increased susceptibility to rubella the incidence of confirmed infection in pregnancy was not found to be higher in Asian than non-Asian women. This is particularly surprising, as the greater parity of Asian women places them at increased risk of exposure from young children. ${ }^{2}$ It suggests, therefore, that Asian women may be less likely to request diagnostic investigation for possible rubella in pregnancy than non-Asian women. This hypothesis was supported by the findings in Luton, where diagnostic requests were proportionately three times less frequent from the Asian than the non-Asian antenatal population. The well recognised phenomenon of late booking by Asian women, a lack of awareness of the dangers of rubella infection among their community, and reluctance to use termination facilities are all factors which are likely to contribute to the underdiagnosis of rubella infection in this group. Given this and their high level of susceptibility to rubella, the twofold increase in notified congenital rubella found in Asian births may underestimate the true size of the problem.

The number of first generation Asian women in Britain is rising as wives come to join their husbands, and these women also have a high fertility rate. ${ }^{8}$ Thus the problem of congenital rubella in Asian babies represents an important challenge to the preventive health services. As well as rubella, the immunisation needs of Asians are likely to include other vaccines, and a comprehensive "protection package" including poliomyelitis, diphtheria, tetanus, and BCG vaccines is required. Asians are easily contacted through their ethnic organisations and tend to register with Asian general practitioners; the vaccination programme could therefore be promoted by these means. The Asian Mother and Baby Campaign, launched in September 1984 with funding by the Department of Health and Social Security, could also play an important part in promoting rubella vaccination in the Asian community. Linkworkers have recently been appointed in one of the areas covered by this study (Luton) and initial results have been encouraging. Health education about the dangers of rubella in pregnancy and of the diagnostic facilities available should also be provided. With appropriate counselling Asians are not as opposed to therapeutic abortion as commonly supposed. ${ }^{9}$

A less readily identifiable group who may be at similar risk to the Asians is other women born abroad. Of the births in England and Wales in 1983 where the mother was born outside Britain, only $45 \%$ were to Asians. A further $33 \%$ (26000 births) were to women from other countries not known to have rubella immunisation

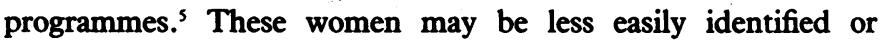
contacted than the Asians, not being part of a well documented 
community with strong ethnic organisations. They are therefore likely to remain susceptible and will be protected only by a policy aimed at national elimination or control of the disease.

The study in Leeds, Luton, and Manchester laboratories was funded by the Office of the Chief Scientist. We thank Miss Pauline Waight, Mr Peter Rushton, Dr Sheila Sheppard, and Mr Gerald Greene for help with data analysis.

\section{References}

1 Peckham CS, Tookey P, Nelson DB, Coleman J, Morris N. Ethnic minority women and congenital rubella. $\mathrm{BrMed}$ f 1983;287:129-30.
2 Miller CL, Miller E, Sequeira PJL, Cradock-Watson JE, Longson M, Wiseberg EC. Effect of selective vaccination on rubella susceptibility and infection in pregnancy. $\mathrm{Br}$ Med $\mathcal{F} 1985 ; 291$ : selective vacin $1398-1401$.

3 Nicoll A, Bassett K, Ulyaszck SJ. What is a name? The accuracy of using surnames and forenames in ascribing south Asian ethnic identity in English populations. $\mathcal{f}$ Epidemiol Community Health (in press).

4 Dudgeon JA, Peckham CS, Marshall WC, Smithells RW, Sheppard S. National congenital rubella surveillance programme. Health Trends 1973;5:75-9.

5 Office of Population Censuses and Surveys. Birth statistics. Ser EM1. Country of birth of mother. London: HMSO, 1974-84.

6 Immigrant Statistics Unit, Office of Population Censuses and Surveys. New Commonwealth and Pakistani population estimates. Population Trends 1977;9:4-7.

7 Miller CL, Miller E. Rubella vaccination in the UK: time for a complete strategy. Lancet 1985;ii:732.

8 Immigrant Statistics Unit, Office of Population Censuses and Surveys. Marriage and birth patterns among the new Commonwealth Pakistani population. Population Trends 1978;11:5-9.

9 Modell B, Petrou M, Ward RHT, et al. Effect of fetal diagnostic testing on birth-rate of thalassaemia major in Britain. Lancet 1984;ii:1383-6.

(Accepted 23 fanuary 1987)

\section{SHORT REPORTS}

\section{“Glue sniffer's" heart?}

Heart failure is rare in British teenagers; solvent abuse is not. ${ }^{1}$ We report on a 15 year old boy with a two year history of intermittent solvent abuse who presented with dilated cardiomyopathy.

\section{Case report}

A previously fit 15 year old white boy developed non-specific chest pains and shortness of breath. One week later he presented to his local hospital with continuing dyspnoea on minimal exertion. He had sniffed glue intermittently for two years: for the initial 12 months he had done so on a regular basis, then he had stopped for six months but subsequently restarted. Generally he used Bostick, in which the principal solvent is toluene. He also smoked both cannabis and tobacco. Two weeks before his presenting illness began he had had what he described as a "heavy session" of glue sniffing.

On admission he was unwell. His blood pressure was $120 / 80 \mathrm{~mm} \mathrm{Hg}$ with a resting heart rate of 110 beats/minute. The jugular venous pressure was raised, but there was no ankle oedema. He had clinical biventricular dilatation and a pansystolic murmur, with a loud pulmonary second sound and a diastolic gallop. Haematological findings, urea and electrolyte concentrations, results of liver function tests, and cardiac enzyme activities were all within normal ranges throughout his illness. He responded to treatment with diuretics and nitrates and was transferred to this hospital.

A chest $x$ ray film showed a slightly enlarged heart (cardiothoracic ratio 14/26), left atrial enlargement, blood diversion in the upper lobe, and Kerley B lines. Two dimensional echocardiography showed all four chambers to be dilated and hypokinetic. The left ventricular ejection fraction measured by first pass radionuclide angiography was $17 \%$ (normal range $>50 \%$ ). He underwent cardiac catheterisation primarily to exclude acute myocarditis. Myocardial biopsy showed chronic myocarditis, with interstitial fibrosis but no evidence of acute inflammatory responses. Findings on catheterisation were: pulmonary artery pressure $50 / 20 \mathrm{~mm} \mathrm{Hg}$ (normal range $15-30 / 5-16 \mathrm{~mm} \mathrm{Hg}$ ), pulmonary artery capillary wedge pressure $24 \mathrm{~mm} \mathrm{Hg}(6-15 \mathrm{~mm} \mathrm{Hg})$, left ventricular end diastolic pressure $32 \mathrm{~mm} \mathrm{Hg} \mathrm{(4-12} \mathrm{mm} \mathrm{Hg),} \mathrm{and} \mathrm{pulmonary} \mathrm{vascular} \mathrm{resistance} 1.3$ Wood units $(1 \cdot 0-1 \cdot 8$ Wood units).

He was allowed home taking digoxin, diuretics, nitrates, salbutamol, and enalapril and remained well for two months, when, after a hot bath, he sustained sudden loss of vision followed immediately by a transient loss of consciousness. His blood pressure was $90 / 65 \mathrm{~mm} \mathrm{Hg} \mathrm{supine} \mathrm{and} 85 / 65 \mathrm{~mm} \mathrm{Hg}$ standing, but after 10 deep knee bends it dropped to $50 \mathrm{~mm} \mathrm{Hg}$ systolic and he again suffered loss of vision. His vision was restored when he lay down. He denied any recent solvent abuse. His diuretics were withdrawn, but this did not improve his clinical state; an intravenous infusion of dobutamine was required to maintain his blood pressure. Despite this his condition deteriorated and he became breathless even at rest. Within 10 days he underwent cardiac transplantation, and 18 months later he was leading a normal life.

The histological appearance of the excised heart was indistinguishable from that of healing myocarditis, although some patchy eosinophilic infiltration made it difficult to exclude a toxic drug reaction. None of the pathological features showed any difference from those of other dilated cardiomyopathies or healed myocarditides seen in the transplant programme.

\section{Comment}

The commonest cause of death in glue sniffers is asphyxiation, ${ }^{2}$ but malignant cardiac arrhythmias have been reported ${ }^{3}$ and are believed to be due to the "physical toxicity" of the dissolved small solvent molecules in the blood. ${ }^{4}$ Acute myocarditis with very high cardiac enzyme activities was reported in a patient who died of cardiac failure after chronic solvent abuse, but there was no association with an acute episode of solvent abuse. ${ }^{5}$ In our patient there was a clear history of chronic solvent abuse, with an acute episode of severe abuse two weeks before admission.

We are grateful to Dr P G I Stovin, consultant pathologist, Papworth Hospital, Cambridge, for his advice on the histological features of the excised heart.

1 Francis J, Murray VSG, Ruprah M, Flanagan RJ, Ramsey JD. Suspected solvent abuse in cases referred to the Poisons Unit, Guy's Hospital, July 1980-June 1981. Hum Toxicol 1982;1:271-80.

2 Anderson HR, Dick B, Macnair RS, Palmer JC, Ramsey JD. An investigation of 140 deaths associated with volatile substance abuse in the United Kingdom (1971-1981). Hum Toxicol associated with

3 Reinhart CF, Azar A, Maxfield ME, Smith PE, Mullins LS. Cardiac arrhythmias and aerosol "sniffing." Arch Environ Health 1971;22:265-79.

4 Clark DG, Tinston DJ. Acute inhalation toxicity of some halogenated and non-halogenated hydrocarbons. Hum Toxicol 1982;1:239-47.

5 Mee AS, Wright PL. Congestive (dilated) cardiomyopathy in association with solvent abuse. J R Soc Med 1980;73:671-2.

(Accepted 16 February 1987)

Department of Cardiology, St Bartholomew's Hospital, London EC1A 7BE MARTIN N WISEMAN, MRCP, cardiac registrar

SEAMUS BANIM, FRCP, consultant cardiologist

Correspondence to: Dr Wiseman.

\section{Myocardial infarction and primary ventricular fibrillation after glue sniffing}

On average 80 deaths each year are associated with solvent abuse; about $27 \%$ of these are related to glue sniffing. ${ }^{1}$ Most deaths are thought to be caused by ventricular arrhythmias, but this has been difficult to confirm owing to the sudden onset of symptoms outside hospital. Documentary evidence of ventricular fibrillation as the primary arrhythmia is rare. We report a case of anterior infarction and primary ventricular fibrillation after prolonged inhalation of an adhesive containing toluene.

\section{Case report}

A previously healthy 16 year old boy, who was a strong swimmer, was seen to fall face down into the local swimming pool while wading in water $1 \mathrm{~m}$ deep. He was immediately taken to the edge of the pool, apparently without inhaling water. At first he was lucid and talking, but five minutes later he suddenly became unconscious. Cardiopulmonary resuscitation was started and a mobile coronary care unit called; on its arrival five minutes later the rhythm was that of ventricular fibrillation. After one direct current shock asystole occurred. Intravenous noradrenaline and calcium chloride resulted in ventricular fibrillation starting again. A further eight direct current shocks were required to restore sinus rhythm. Boluses of lignocaine $200 \mathrm{mg}$, mexiletine $200 \mathrm{mg}$, and amiodarone $200 \mathrm{mg}$ plus an infusion of amiodarone $1500 \mathrm{mg}$ over 24 hours were required to control the rhythm. He was intubated and transferred to intensive care.

On arrival he was unconscious and not breathing spontaneously. Astrup $\mathrm{pH}$ was $7 \cdot 27$, oxygen tension $14 \cdot 0 \mathrm{kPa}$, carbon dioxide tension $6.7 \mathrm{kPa}$, base 